PROBLEMS

OF EDUCATION IN THE $21^{\text {st }}$ CENTURY Vol. 79, No. 5, 2021

716

\section{NONSTANDARD MATH WORD PROBLEMS AND ANALYSIS OF THE PARTIAL STAGES OF ITS SOLUTION}

\author{
Michaela Surá \\ Preschool and Primary School Grygov, Czech Republic \\ E-mail: misasura@seznam.cz
}

\begin{abstract}
Choosing the right strategy is an important condition to successfully solve math problems. Research studies often present individual types of strategies more or less separately. This study aims to determine student solutions of selected word problems in the whole context of the solution process. In this context, such nonstandard word problems combine verbal formulation and the character of nonstandard problems (impossible to be solved using an algorithm). In order to get an overall picture of the stages of word problem solution, an analysis of solving a given word problem was conducted among 171 respondents aged 10-11. The analysis was conducted in compliance with partial steps of word problem processing, as the solving of the problem was viewed from a wider perspective. The student's reaction to the problem, working with the given information, individual forms of solution, and answer formation were recorded. In order to have a more complex idea and possibility to compare, the chosen way of solving the problem was also presented to a selected sample of 26 teachers. Available solutions were analyzed, and there were sought ways how the solution was assessed by the teachers based on selected parameters. Especially their meta-cognitive estimation of the correctness of their own solution was subject to scrutiny.

Despite the fact that the respondents chose different strategies of solution (graphic, arithmetical, using judgment, etc.), it appears that the success rate of solving the given nonstandard word problem was very low. Thus, it is necessary to implement such word problems into standard math lessons, also within pregraduate teacher preparation.
\end{abstract}

Keywords: mathematics teaching, primary school mathematics, problem-solving, prospective teachers, word problem

\title{
Introduction
}

The basis term used throughout this research is the term problem (meaning word problem). According to (Kuřina, 2011) by solving suitable problems an individual improves his/her understanding of math. Word math problems and their solutions have been discussed in many publications by both Czech and foreign researchers (Adams, 2003; Gravemeijer, 1997; Palm, 2009). According to (Freudenthal, 1983; Polya, 1990) and others terminology of school math is not united in terms of mathematical word problems.

Nonstandard word problems are a category of nonstandard problems that combine verbal formulation and the character of nonstandard problems. A word problem can be understood as a practical problem with a real context containing a problem that can be solved using mathematical 
means. Adams defines the word problems as "mathematical problems presented in the context of a story or real-life scenario" (Adams, 2003, p. 790). Czech researchers Blažková et al. say, that "word problems are such problems in which the correlation between the given and sought for data is expressed by verbal formulation. Using appropriate reasoning we consider what numerical operations it is necessary to perform with the given data in order to answer the question of the word problem. The principle of solving these problems is to create a mathematical model of the given situation expressed by the text of the word problem. The transition from the real-life situation to the corresponding mathematical model is called mathematization of a real situation. What we understand by this is the expression of the relations between the specified data and the sought for result in the language of mathematics. Solving the given math problem we get a result that needs to be confronted with the verbal formulation of the word problem." (Blažková et al., 2001, p. 4)

In order to define what is nonstandard, the research starts with the definition of nonstandard problem, which is normally defined as: "A problem task is such a task/problem for the solution of which the experience of the students acquired to date, or the stereotypes acquired in school are not enough. Certain mathematical creativity and imagination are necessary to solve such problem tasks. The student solves the problem independently, using his/her own active examination. Observing the known the students learn to discover the unknown, developing their wit and logical thinking." (Budínová et al., 2018, p. 54)

This research was based on detailed analysis of solving nonstandard math word problems. Four main phases were examined in terms of the respondents' solutions that led to the correct solution. The first is the student's reaction on his/her first contact with the word problem, which subsequently accompanies the way they solve the problem. Hejný (1995) mentions three possible reactions by the solver to the problem. The first is direct, which means the solver has accepted the challenge and is trying to solve it as best he/she can, applying both his/her knowledge and intuition. The second type of reaction is evasive. The solver wants to solve the problem or at least pretend that he/she is working on it. However, for unknown reasons they never solve it. A typical evasive reaction is copying. The third and last reaction is resignation. The student does not even attempt to solve the problem. Instead, he/she directly refuses to even try to solve it. There might be multiple reasons for this kind of reaction, either those mentioned above, or the problem simply appears to be too difficult for him/her.

In the next phase there was examined the way the respondents wrote down the information included in the assignment of the word problem (word problem analysis). This analysis usually includes a brief assignment of the task, may include graphic representation, and is meant to help find relations between the objects of the task. Some researchers distinguish between substantive content analysis and mathematical content analysis (Novák \& Stopenová, 1993). Substantive content analysis is the basic insight into the word problem. Using mathematical content analysis, the solver distinguishes the conditions of the problem (information included in the assignment), and questions of the problem (what the solver is supposed to find, and thus what later needs to appear in his/her answer). If the solver is able to determine the conditions as well as the questions of the problem, it is likely that he/she understands the word problem situation, and is able to understand the relations between the conditions and the question (Novák \& Stopenová, 1993). For small children it is difficult to write down the word problem assignment, but fifth grade students who formed our research sample should already be used to doing it.

Research studies usually consider choosing the correct strategy usually as the most important thing (Eisenmann et al., 2017; Elia et al., 2009; Novotná et al., 2012). Drawing schemes and pictures (for a better understanding of the problem) is one strategy for solving word problems (Budínová et al., 2018). If the solver uses calculations, we call this the arithmetic solution. It is the most frequently used solution in school practice, although not the only one. In the course of mathematization of a real life situation, or even prior to it, the solver may use a

$\mid \begin{aligned} & \text { PROBLEMS } \\ & \text { OF EDUCATION } \\ & \text { IN THE } 21^{\text {st }} \text { CENTURY } \\ & \text { Vol. 79, No. 5, } 2021\end{aligned}$ 
Radka DOFKOVÁ, Michaela SURÁ. Nonstandard math word problems and analysis of the partial stages of its solution

PROBLEMS

OF EDUCATION

IN THE $21^{\text {st }}$ CENTURY

Vol. 79, No. 5, 2021

718

different kind of solution. Other types of solution are algebraic solutions in which solvers work with equations with one or more unknowns. However, algebraic solutions are not very common among children aged 6-11.

For the purposes of the research, we understand nonstandard word problems in primary schools to be such that have the following characteristic features: they are formulated verbally, are set in a real context, have a mathematical content, and require more complex thinking operations of those who solve them (cannot be solved using a known algorithm).

\section{Research Problem}

Nonstandard word problems require a specific approach to their solution despite the fact that they are based on the solution of standard word problems (Polya, 1990; Reed, 2017; Reusser, 1985, 1992; Sternberg, 2003), and within their solution of nonstandard word problems in primary school for student in age 6-11 use different strategies to solve them: solution based on insight, graphic solution, arithmetical solution, experimental solution, etc. (Eisenmann et al., 2017; Novotná, 2000).

\section{Research Focus}

Many domestic and foreign researchers have mentioned students' difficulties solving word and nonstandard word problems (Dofková \& Chudý, 2019; Dofková \& Kvintová, 2019b, 2019a). Ahmad (2010, p. 356)2003, claimed that "successful problem solvers spend more time analyzing a problem and they will find all the alternatives related to the situation." The aim of research was to give a complex view of the solution of nonstandard word problems (logical problems solved by insight) from the respondent's first contact (his/her reaction to the problem), way of working with the given information, the chosen strategy, and formulating the answer. The results are accompanied by the solution of the given problem by elementary school math teachers.

\section{Research Aim and Research Questions}

The aim of the research was a detailed analysis of the phases of solving nonstandard word problems from a complex point of view - the reaction of the solver to the question, working with assigned information, strategies used, and formulating answers. Thus, the aim of the analysis of results was to categorize the respondents' solutions (in individual stages of solving the problems), and to examine the connection between the form of the solution and the home class of the respondents and their gender.

Within research the following questions were formulated:

- (RQ1) How do the students react to a nonstandard word problem (a logical one solved by judgment)?

- (RQ2) How do the students work with information specified within the given problem?

- (RQ3) What strategies of solution of the given problem do the students choose?

- (RQ4) How do the students formulate the answer to the given question?

\section{Research Methodology}

\section{General Background}

Among those who dealt with the classification of nonstandard word problems in the Czech Republic were, for example (Budínová et al., 2018; Lišková \& Rezek, 2015). Each of them took 
a different approach to the classification of nonstandard word problems. There are the logical solutions solved by judgment, inversely formulated word problems, problems with redundant or missing data (captain problems), combinatorial problems (Diofantine problems). Different understanding of specific meanings makes further orientation and attempts to systematize word problems harder. This research was focused on nonstandard problems that were discussed in the diploma thesis by (Surá, 2020).

The research was conducted in 2020. Its aim was to create a 45-minute didactic test that included the selected word problem. Distribution was carried out in the form of offering collaboration that was sent to all elementary schools in Olomouc. Schools that accepted the offer to partake in the research paid for all the relating administration, printing assignments, and selecting tests. Based on mutual agreement the didactic tests were submitted for the analysis of solutions.

The analysis of solutions was conducted by qualitative assessment of individual phases of the processing of the word problem. In each nonstandard word problem used it was possible to follow the approach of the solver or his/her reaction to the problem. The analysis further dealt with the form of entry and working with the provided information, the type and form of solution, and also the form of answer. As the individual tests also included scales of their relation to nonstandard word problems, a short assessment of this data can be assumed. As every assigned word problem has a correct result, it was also appropriate to mention the success rate and successful solvers.

\section{Sample}

The distribution of the word problem was done within the research for a diploma work (Surá, 2020). The nonstandard word problem was sent in text document to 17 primary schools in the Olomouc Region in the Czech Republic. The schools were addressed via the school principals' email, the schools engaged in the project on a voluntary basis. A total of nine classes took part in the research, which means $1715^{\text {th }}$ grade primary students - age 6-11 (80 girls and 91 boys). Individual categories were indexed based on the schools they were from - S1.1, S1.2, S1.3, S2.1, S3.1, S3.2, S3.3, S3.4, S3.5.

In order to get feedback from teachers, 26 elementary school teachers, who were studying in a combined form of study at the Teacher Education Faculty, were asked to solve the word problem and to comment on it in terms of methodology. They were supposed to solve the problem using strategies available for primary school students, and methodologically comment on the given value. The sample of teachers was chosen without any connection to the sample of students. The solution presenting was anonymous.

\section{Instrument and Procedures}

The nonstandard word problem chosen for further examination was: A brick weighs $2^{1}$ kilograms and half of the brick. How much does the brick weigh? (Budínová et al., 2018, p. 57).

This is a task that at first glance seems to many pupils and students to be meaninglessly assigned. For a similar type of problem, either a graphical representation or a plot using the scales seems to be the optimal solution (Figure 1).

\footnotetext{
1 There is using a Czech version of the word brick - ,cihla“. It is used only in the part where it is necessary for the authenticity of the text.
} 
PROBLEMS

OF EDUCATION

IN THE $21^{\text {st }}$ CENTURY

Vol. 79 , No. 5, 2021

720
Figure 1

Graphic Solution of the Task

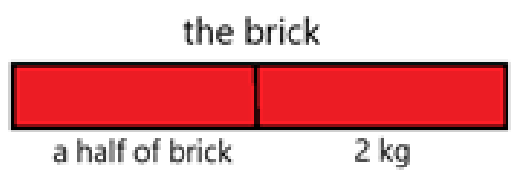

The illustration using scales is based on the fact that the two parts of the brick must be in balance. From both graphic models, it is clear that the weight of half of the brick corresponds to the weight of its other half $(2 \mathrm{~kg})$ and the whole brick, therefore, weighs $2 \mathrm{~kg}$.

Of course, the problem also has a possible algebraic solution using the equation $\mathrm{b} / 2+2=$ 4. However, this solution does not correspond to the cognitive level of students aged 6-11 years.

The validity of the already finished test was assessed by means of pre-research. Its aim was to get a reaction of a group of teachers to the selected nonstandard word problems in selected schools. The assessment and teachers' comments were analyzed and compared. Acquired comments were helpful in the selection of particular word problems for the main part of the research (Surá, 2020).

\section{Data Analysis}

The analysis of the solution was performed using qualitative assessment of the individual stages of processing the word problem. In each nonstandard word problem, it was possible to follow the student's approach to it, his/her reaction to the word problem. The analysis also dealt with the form of writing down the given information, kind and form of solution, and last but not least the form of the answer.

The data were processed in two stages. In Stage 1 classification of the word problems and their categorization based on their common features took place. For a better overview each test was marked with a code formed by a letter and a figure. Tests for one class were first categorized based on the respondents' gender, and then based on their results in math that were mentioned in the first box of the test. In Stage 2 the analysis of individual solutions took place. For better overview, quantitative data analysis was complemented with basic descriptive statistics of data processed using MS Excel.

\section{Research Results}

While analyzing the results it was found that only six respondents came up with the correct result. Thus, it turned out as very useful to conduct a closer analysis of the students' approach to word problems. Each submitted solution was thus examined in terms of the students' reaction to the problem, their working with the given information, chosen solution, and formulating the answer. 
Students' reaction to the problem. The first aspect of the word problem to be examined was the students' reaction to it. It turned out to be useful to classify resignation as a respondent's reaction to the problem in greater detail - primary resignation (the respondent resigned upon reading the word problem, without trying to process it at all), and secondary resignation (the respondent attempted to solve the problem, but then resigned and deleted all the solutions he/ she had created using a correction pen or crossing them. ${ }^{2}$

\section{Figure 2}

The Respondents' Reaction to Word Problem

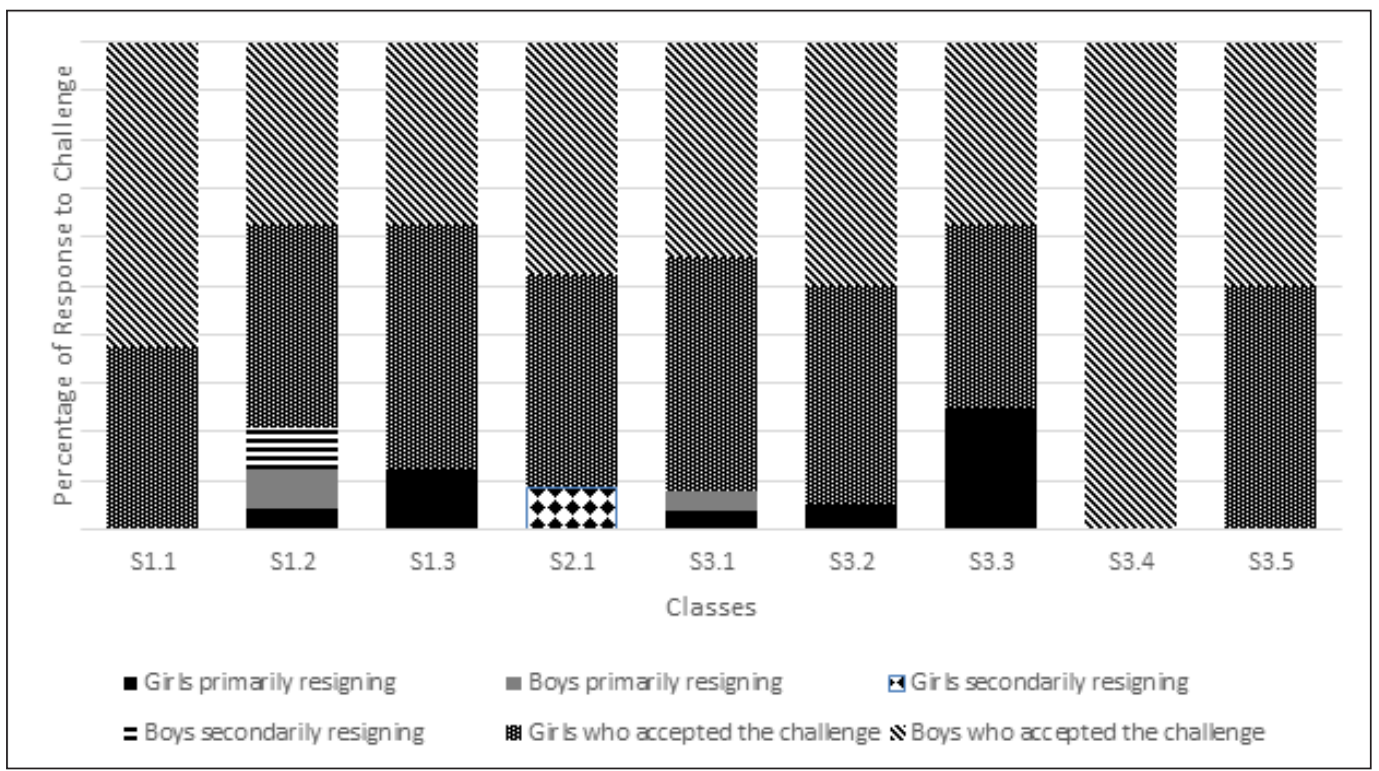

In the course of the analysis, it was found that girls had generally resigned sooner than boys (Figure 2). Only in two grades was there a slightly bigger number of students who resigned than those who did not - in classes S1.2 (21\%) and S3.3 (25\%). Compared to that, there were three classes in which no one resigned (S1.1, S3.4, and S3.5).

Students' working with specified information. It was only possible to analyze the students' working with the specified information in $7 \%$ of the students who had attempted it. Out of those five respondents chose underscoring important information while eight drew it up. The distribution of the respondents based on the classes is shown in the following chart (Figure $3)$. In four classes there was not a single respondent working with information. The biggest number of respondents working with the assignment of the word problem was in Class S3.1, where four boys and one girl worked with it.

$2 \quad$ It is possible to define also tertiary resignation by the respondents (resignation after initial effort). However, this was not closely examined in the course of the research.

\begin{tabular}{|l} 
PROBLEMS \\
OF EDUCATION \\
IN THE 21 $1^{\text {st } C E N T U R Y ~}$ \\
Vol. 79, No. 5, 2021 \\
\hline 721
\end{tabular}


PROBLEMS

OF EDUCATION IN THE $21^{\text {st }}$ CENTURY Vol. 79 , No. 5, 2021

722

Figure 3

Working With the Assignment

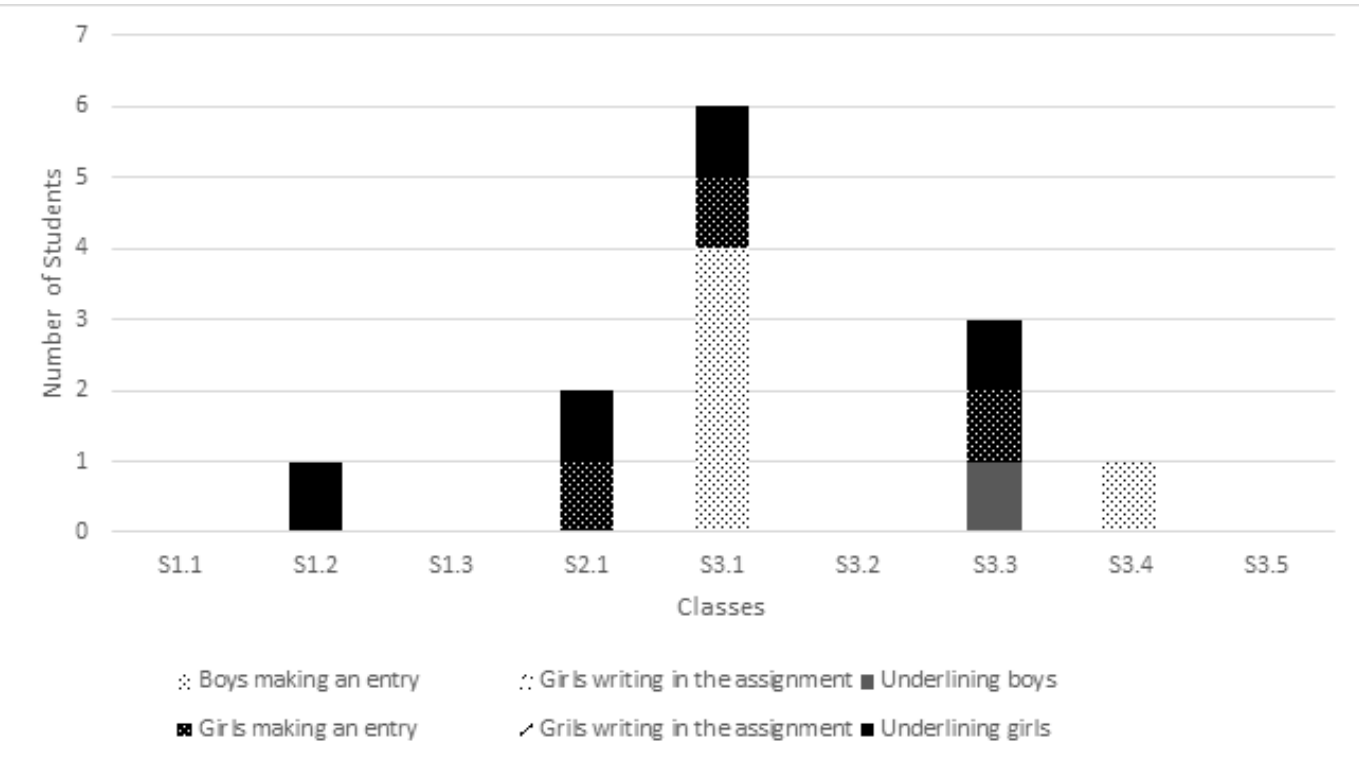

Graphic solution by students. Seven respondents chose graphic solution to the word problem. Five of them drew the brick as a rectangle to which they marked a smaller part of the brick (Figure 4a).

Figure 4a, b

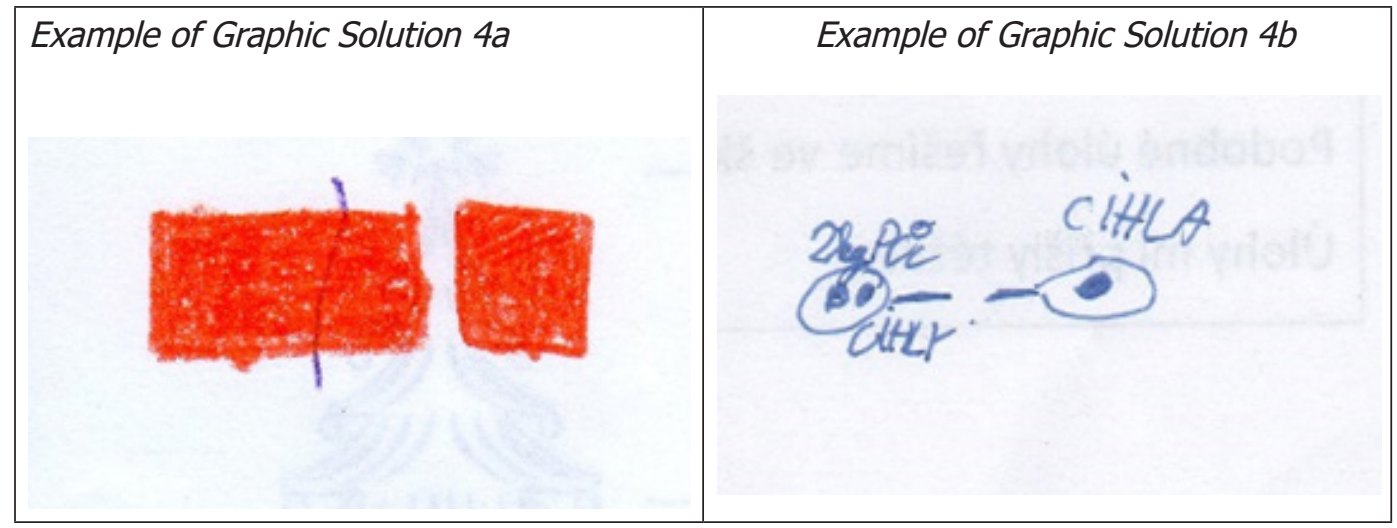

A similar graphic solution was used by respondents F1 and S4. Respondent S4 (a boy) drew just a brick weighing two kilograms. Respondent F1 (a girl) made a similar drawing of a two-kilogram brick, next to which she drew a smaller brick, whose weight she estimated to be half-a-kilogram or one kilogram.

A second variant of graphic expression of the weights is one chosen by two respondents. Respondent Z4 reached the correct solution thanks to his graphic expression of the weights (Figure 4b).

Arithmetic solution of the word problem by students. Arithmetic solution was chosen by a total of $19.29 \%$ of the respondents. Two respondents, girls A5 and H4, chose multiplication 
as the first arithmetic operation. These two respondents were the only two to use product, and also the only two to have reached the correct result using an arithmetic solution.

The remaining part of the respondents used the operation of division to express the division of a two-kilogram brick into two halves, and then add one half to it. As most of the respondents were able to calculate one half of two in their heads, some respondents directly added this value. One respondent instead of dividing, subtracted the value of one and then added it to reach the value of 3, just like another 76 respondents in this research. Another 31 respondents used arithmetic solution to solve this word problem. Even though they chose various initial operations, the original idea remained the same. Figure 5 is an example of such a solution.

\section{Figure $\mathbf{5}$}

Example of Arithmetic Solution ${ }^{3}$

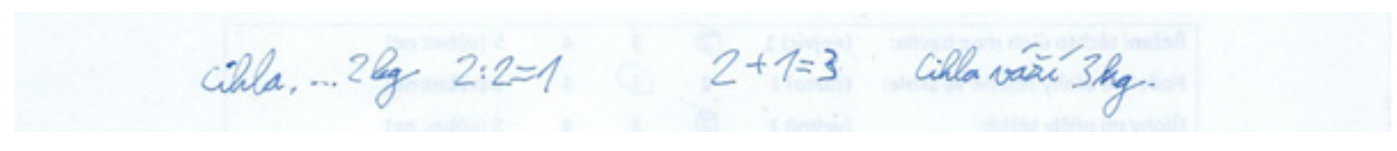

Formulation of answers to the word problem by the respondents. Only two respondents answered numerically, another $19 \%$ numerically plus the given unit, and a total of $67 \%$ of the respondents formulated the answer verbally. Specifically, $44 \%$ of the respondents formulated the answer as follows: "The brick weighs x kilograms"; 11\% wrote "One brick weighs $\mathrm{x}$ kilograms". Other formulations were, for example: $1.50 \mathrm{~kg}$ is what the brick weighs"; "It weighs 3 kilograms"; "There were 3 kilograms of the brick"; "The total weight is x kilograms".

In this word problem it was possible to see the entry of kilograms in the individual answers. The respondents mostly used the full wording of "kilograms" or "kg", only few wrote "kilos". In the answers "kg" was used the most; about three times as often as "kilograms". 7\% of the respondents made grammar mistakes. Spelling mistakes occurred in the words: kilograms and bricks.

The word problem as seen by the teachers. In order to gain feedback for the teacher, the word problem was given within teaching students of combined form of study. They were supposed to assess the word problem from a meta-cognitive point of view of guessing own success rate. Verbal assessment of the word problem was also required.

In the area of meta-cognitive assessment, a total of $15.4 \%$ of the respondents stated they had been wrong solving the problem, $19.25 \%$ thought they were probably wrong solving the problem, $53.85 \%$ thought they probably answered correctly, and $11.55 \%$ were sure they did.

The analysis of the solution found that $26.9 \%$ of the teachers used an algebraic way of solution, $61.5 \%$ solved it by judgment, $7.7 \%$ used a combination of graphic solution and an arithmetic or algebraic way, and one respondent resigned completely. It is necessary to say that half of the respondents who used judgment wrongly claimed that the brick weighed $2.5 \mathrm{~kg}$.

The overall impression from the word problem and the ways of its solving by the teachers are accompanied with their verbal assessments, such as: "witty task"; "Logic, logic, logic. Very nice"; "It is quite a simple result. Just the assignment may seem tricky at first sight"; "I didn't quite understand the assignment"; "I'm not sure if I could come up with another solution than that of an equation with one unknown. I think it's too difficult for elementary school, "the assignment is more of a riddle", "The word problem is simple if you understand the assignment", "the word problem seemed easy to me to understand the wording". 
PROBLEMS

OF EDUCATION

IN THE $21^{\text {st }}$ CENTURY Vol. 79, No. 5, 2021

724

\section{Discussion}

The most problematic part of the task was the understanding of the assignment. Consistent with other research, understanding the text of a word problem is key to its successful solution, and therefore mathematical word problems should always take into account the nature of the language used in the problem and the situation chosen for the task (Adams, 2003; MacGregor, 2002; Sepeng \& Sigola, 2013).

The results of the research showed that most of the students who solved correctly used a graphic solution. This contradicts the results of some authors, which show that graphical representation does not support the solution of mathematical problems or may be difficult for them (Hewitt, 2003). On the other hand, other results show that students' graphic design preferences mostly depend on whether their teacher uses them (Ahmad et al., 2010). Woolner (2004) emphasized that, for this reason, future teachers need to be encouraged to incorporate graphic solutions into their teaching.

The research has shown that, similarly as in (Eisenmann et al., 2017), there are strategies that may appear in students spontaneously while solving the selected type of word problems. Heuristic strategies identified by us were in fact chosen by the students while solving the submitted word problems without the students' being taught about them. This finding corresponds to the results (Henningsen \& Stein, 1997) that suggest that the teacher must both choose and suitably adjust useful math problems. However, the teacher must also actively choose and support cognitive activity of the students without decreasing the difficulty and cognitive difficulty of the math problem.

As the research instrument was limited to only one word problem, we cannot generalize whether the students used strategy flexibility (Elia et al., 2009) while solving the word problem. It can only be summarized that some solutions contained signs of changing various solving strategies. However, these were not very successful.

Choosing a task in the test also showed that solving non-standard word problems is a process requiring broad skills and strategies (Landi, 2009) and that such tasks are difficult for students. The way to solve this is to include these tasks in the teachers' training, who will then be able to implement the tasks in the teaching of elementary mathematics.

Many recent research studies have, for example, dealt with finding critical places in mathematics from the viewpoint of teaching primary mathematics (Dofková \& Kvintová, 2017; Vondrová, 2019), finding students' potential using creative mathematics and motivational approach (Boaler, 2016), or determining the order of information in the assignment of a word problem (Vondrová et al., 2019). This research is unique namely in the fact that it analyzes the given word problem in its complex context, combining both the students' solution and the teachers' solution and methodological assessment.

It is obvious that our research project had certain limitations. As it was conducted in the form of quantitative research, with an emphasis laid mainly on depth analysis of individual solutions, it was not possible to study a broader sample of respondents. Still, we can hypothesize that the presented results have a sufficient predictive value in respect to the width of their processing, and that they can serve as a basis for further research. At the same time, it would be useful include a bigger number of nonstandard word problems thus the students could use more strategies to solve them, and it would be possible to further compare not only the successful solutions but also, for example, in respect to the field of mathematics (geometry, arithmetic, etc.).

\section{Conclusions and Implications}

In compliance with the above formulated research questions, we can make the following 
conclusions. After processing the tests based on the author's reaction to the problem it turned out that most of the respondents accepted the challenge, however, with only a $4 \%$ success rate. As the assignment was short and did not contain a lot of information, it could seem easy to most respondents at first sight, which might be one of the reasons why there is a higher number of classes where all students accepted the challenge. The same reason probably meant that only a small percentage of them worked with the assigned information.

The students most frequently chose graphic and arithmetical solutions to the problem. None of them solved it by judgment or experiment. These ways (together with the algebraic way of solving it) were typical for solutions by teachers from practice. These respondents also had a higher success rate (65\% of correct answers). Formulating the answer was at a good level. The number of respondents that used correct syntax in their answer was greater than that of those who answered correctly.

The research results thus correspond to the published conclusions of many researchers. They state that solving word problems or nonstandard word problems can still be understood as a critical point in teaching math. It is necessary to teach math in a challenging environment, in which word and nonstandard problems were understood as an environment for the development of the student's personality.

\section{Acknowledgements}

This research was done with the support of the internal grant Mathematical education and its reflection in publication outputs according to Methodology $17+$.

\section{Declaration of Interest}

Authors declare no competing interest.

\section{References}

Adams, T. L. (2003). Reading Mathematics. More than words can say. The Reading Teacher, 56(8), 786-795. https://doi.org/10.1007/978-1-4684-9137-1_48

Ahmad, A., Tarmizi, R. A., \& Nawawi, M. (2010). Visual representations in mathematical word problem solving among form four students in Malacca. Procedia - Social and Behavioral Sciences, 8(5), 356-361. https://doi.org/10.1016/j.sbspro.2010.12.050

Blažková, R., Matoušková, K., \& Vaňurová, M. (2001). Kapitoly z didaktiky matematiky [Chapters from didactics of mathematics]. https://is.muni.cz/el/1441/podzim2016/SZ_9005/um/Skripta-sobr.pdf

Boaler, J. (2016). Mathematical Mindsets. John Wiley \& Son.

Budínová, I., Blažková, R., Vaňurová, M., \& Durnová, I. (2018). Úlohy z matematiky pro bystré a nadané děti prvního stupně ZŠ, jejich učitele a rodiče: škály pro identifikaci nadání, zkušenosti s nadanými žáky [Mathematical problems for gifted primary school children, their teachers and parents: scales for identifying (Edika). Albatros Media.

Dofková, R., \& Chudý, Š. (2019). Weak and strong points in the perception of own preparedness of prospective math teachers. Prosodi, 13(1), 67. https://doi.org/10.21107/prosodi.v13i1.5350

Dofková, R., \& Kvintová, J. (2017). Vnímání vlastní efektivity učitelio primárního vzdělávání [The perception of own effectiveness of primary education teachers: qualitative analysis of mathematics and didactics readiness in pre-graduate preparation]. Univerzita Palackého v Olomouci.

Dofková, R., \& Kvintová, J. (2019a). Personality Development of Prospective Mathematics Teachers. In Personality Development of Prospective Mathematics Teachers (Issue March). Univerzita Palackého v Olomouci. https://doi.org/10.5507/pdf.19.24456409

Dofková, R., \& Kvintová, J. (2019b). Preparedness of pre-service primary school teachers for error handling in mathematics. INTED2019 Proceedings, 1(March), 2340-2344. https://doi.org/10.21125/inted.2019.0646 
Radka DOFKOVÁ, Michaela SURÁ. Nonstandard math word problems and analysis of the partial stages of its solution

PROBLEMS

OF EDUCATION IN THE $21^{\text {st }}$ CENTURY Vol. 79 , No. 5, 2021

726

Eisenmann, P., Přibyl, J., Novotná, J., Břehovský, J., \& Cihlář, J. (2017). Volba heuristických strategií v závislosti na věku [Choice of heuristic strategies depending on age]. Scientia in Educatione, 8(2), 21-38. https://www.researchgate.net/publication/336742478_Volba_resitelskych_strategii_v_ zavislosti_na_veku

Elia, I., van den Heuvel-Panhuizen, M., \& Kolovou, A. (2009). Exploring strategy use and strategy flexibility in non-routine problem solving by primary school high achievers in mathematics. ZDM - International Journal on Mathematics Education, 41(5), 605-618. https://doi.org/10.1007/s11858-009-0184-6

Freudenthal, H. (1983). Didactical phenomenology of mathematical structures. Springer Science \& Business Media.

Gravemeijer, K. (1997). Solving word problems: A case of modelling? Learning and Instruction, 7(4), 389-397. https://doi.org/10.1016/s0959-4752(97)00011-x

Hejný, M. (1995). Zmocňování se slovní úlohy [Seizing the verbal exercise]. Pedagogika, 4, 386-399.

Henningsen, M., \& Stein, M. K. (1997). Mathematical tasks and student cognition: Classroom-based factors that support and inhibit high-level mathematical thinking and reasoning. Journal for Research in Mathematics Education, 28(5), 524-549. https://doi.org/10.2307/749690

Hewitt, D. (2003). Notation Issues: Visual Effects and Ordering Operations. Proceedings of the 27th Conference of the International Group for the Psychology of InMathematics Education Held Jointly with the 25th Conference of PME-NA, 3(1994), 63-69.

Kuřina, F. (2011). Matematika a řě̌ení úloh [Mathematics and problem solving]. Jihočeská univerzita v Českých Budějovicích, Pedagogická fakulta. http://mdisk.pedf.cuni.cz/SUMA/ MaterialyKeStazeni/PublikaceKnihy/KurinaMatematikaARU.pdf

Lišková, H., \& Rezek, P. (2015). Tematický okruh Nestandardní aplikační úlohy a problémy [Thematic area Non-standard application tasks and problems]. In E. Fuchs \& E. Zelendová (Eds.), Metodické komentáře ke Standardìm pro základni vzděláváni [Methodical Comments of Standards of Education] (pp. 105-132).

MacGregor, M. (2002). Using words to explain mathematical ideas. The Australian Journal of Language and Literacy, 25(1), 78-88.

Novák, B., \& Stopenová, A. (1993). Slovní úlohy ve vyučování matematice na 1. stupni ZŠ [Word tasks in primary mathematics teaching]. Univerzita Palackého v Olomouci.

Novotná, J. (2000). Analýza řě̌ení slovních úloh [Analysis of word problem solving]. Pedagogická fakulta, Univerzita Karlova.

Novotná, J., Eisenmann, P., Přibyl, J., Ondrušová, J., \& Břehovský, J. (2012). Problem solving in school mathematics based on heuristic strategies. Journal on Efficiency and Responsibility in Education and Science, 7(1), 1-6. https://doi.org/10.7160/eriesj.2014.070101

Palm, T. (2009). Theory of authentic task situations. In L. Verschaffel, B. Greer, W. Van Dooren, S. Mukhopadhyay, \& V. Dooren (Eds.), Words and Worlds: Modelling Verbal Descriptions of Situations (pp. 3-19). Sense Publishers.

Polya, G. (1990). How to solve it: The classic introduction to mathematical problem-solving - with a foreword by Ian Stewart. Penguin Books.

Reed, S. K. (2017). Problem solving. In S. E. F. Chipman (Ed.), The Oxfort handbook of cognitive science (pp. 231-247). Oxfort University Press.

Reusser, K. (1985). From situation to equation on formulation, understanding and solving "situation problems. University of Colorado, Deparment of Psychology. Technical Report No. 143. https:// www.researchgate.net/publication/280802997_From_Situation_to_Equation_On_formulation understanding_and_solving_situation_problems

Reusser, K. (1992). Kognitive Modellierung von Text-, Situations-und mathematischem verständnis beim Lösen von Textaufgaben [Cognitive modeling of text, situation and mathematical understanding when solving word problems]. In Maschinelles Lernen (pp. 225-249). Springer.

Sepeng, P., \& Sigola, S. (2013). Making sense of errors made by learners in mathematical word problem solving. Mediterranean Journal of Social Sciences, 4(13), 325-333. https://doi.org/10.5901/mjss.2013.v4n13p325

Sternberg, R. (2003). Cognitive psychology. Wadsworth.

Surá, M. (2020). Nestandardní slovní úlohy a jejich řě̌ení [Non-standard word tasks and their solution]. Pedagogická fakulta, Univerzita Palackého v Olomouci. 
Vondrová, N. (2019). Didaktika matematiky jako nástroj zvládání kritických míst v matematice [Didactics Vol. 79, No. 5, 2021 of mathematics as a tool for managing critical points in mathematics]. Pedagogická fakulta, Univerzita Karlova.

Vondrová, N., Havlíčková, R., Hrischová, M., Chvál, M., Novotná, J., Páchová, A., Smetáčková, I., Šmejkalová, M., \& Tůmová, V. (2019). Matematická slovní úloha [Mathematics word task]. Karolinum.

Woolner, P. (2004). A Comparison of a Visual-spatial approach and a verbal approach to teaching mathematics. In 28th Conference of the International Group for the Psychology of Mathematics Education, 4, 449-456. http://emis.ams.org/proceedings/PME28/RR/RR006_Woolner.pdf

Received: April 19, 2021

Accepted: October 01, 2021

Cite as: Dofková, R., \& Surá, M. (2021). Nonstandard math word problems and analysis of the partial stages of its solution. Problems of Education in the 21 $1^{\text {st }}$ Century, 79(5), 716-727. https://doi.org/10.33225/pec/21.79.716

\section{Radka Dofková}

(Corresponding author)

Associate Professor, Head of Department of Mathematics, Faculty of Education, Palacký University Olomouc, Žižkovo nám. 5, 77140 Olomouc, Czech Republic.

E-mail: radka.dofkova@upol.cz

Website: katmat.upol.cz

ORCID: https://orcid.org/0000-0002-9568-6281

\section{Michaela Surá}

Primary School Teacher, Elementary School and Kindergarten Grygov, Komenského 72, 78373 Grygov, Czech Republic.

E-mail: michaela.sura@zs-grygov.cz

Website: https://zs-grygov.cz/

ORCID: https://orcid.org/0000-0002-4813-0731 